\title{
Prevalence of intestinal parasitic infections and associated risk factors among students at Dona Berber primary school, Bahir Dar, Ethiopia
}

Tamirat Hailegebriel

\begin{abstract}
Background: Intestinal parasitic infections are still one of the major health concerns in developing countries. Monitoring of intestinal parasitic infection and associated risk factors are essential for intervention strategies. Therefore, the aim of this study was to assess the prevalence of intestinal parasitic infection and associated risk factors among students at Dona Berber primary school, Bahir Dar, Ethiopia.

Methods: School based cross-sectional study was conducted among students at Dona Berber primary school from October 2015 to June 2016. Three hundred fifty nine students were involved in the study by providing stool specimens and detailed personal information. Students were selected by stratified and systematic random sampling method. Fresh stool samples were collected from each student and processed by formal-ether fecal concentration technique. Data were analyzed using SPSS version 20.0 statistical software and $p$ value $<0.05$ were used as statistically significant.

Results: Among the 359 students participated in the study, 235 (65.5\%) were infected by one or more intestinal parasites. The rates of single and double parasitic infections among students were $49.6 \%$ and $16.2 \%$, respectively. The most prevalent parasite detected in the study was E. histolytica/dispar (24.5\%) followed by hookworm (22.8\%). Among the different variables assessed in the study, family size of $6(\mathrm{AOR}=4.90 ; 95 \% \mathrm{Cl}, 2.03-11.83)$, irregularly shoe wearing habit $(A O R=2.85 ; 95 \% \mathrm{Cl}, 1.53-5.32)$ and unclean finger nail $(\mathrm{AOR}=3.68 ; 95 \% \mathrm{Cl}, 1.87-7.26)$ were independently predict intestinal parasitic infections. Student drinking well water ( $\mathrm{AOR}=2.51 ; 95 \% \mathrm{Cl}, 2.30-4.86)$ and unclean finger nail $(A O R=4.42 ; 95 \% \mathrm{Cl}, 2.55-7.65)$ were strongly associated with $E$. histolytica/dispar infection. Likewise, irregular shoe wearing habit (AOR $=14.13 ; 95 \% \mathrm{Cl}, 7.06-28.29$ ) was strongly associated with hookworm infections.
\end{abstract}

Conclusion: High prevalence of intestinal parasitic infection among the study participants demands improvement of health education, environmental sanitation and quality of water sources.

Keywords: Intestinal parasite, School children, Risk factors 


\section{Background}

Intestinal parasitic infection is one of the major health problems globally and up to 3.5 billion people are infected and around 450 million people are ill due to intestinal parasites [1]. The majority of these intestinal parasitic infections are concentrated in developing countries. The problem are more serious in Sub-Saharan Africa, Asia and Latin America associated with inadequate water supply, environmental sanitation, fast population growth, and other economic and social and problems [2].

Intestinal parasitic infections are more prevalent among children as compared with the general population. About $12 \%$ of the global disease burdens caused by intestinal parasites is observed among children with age ranges from 5 to 14 years in developing countries [3]. Up to 270 million preschool and 600 million school children are living in area where high transmission of parasitic worm [4]. These indicated that children are the major risk group for parasitic infection in many developing countries.

Protozoa and helminthic parasites are the known parasites that affect the gastrointestinal cavity. Intestinal parasites such as Ascaris lumbricoides, Trichuris trichiura and hookworm are the most prevalent and affect about one-sixth of the world population [5]. A. lumbricoides is responsible for about 1.2 billion infections globally while $T$. trichiura and hookworm infection accounts about 795 million and 740 million, respectively [6]. Among the protozoan parasite, E. histolytica and Giardia lamblia are the most dominant cause of intestinal morbidity in children.

High prevalence of intestinal parasitic infection were reported among school children in Sub Saharan African countries including $27.7 \%$ to $95 \%$ [7-14] in Ethiopia, 90\% in Central Sudan [15], 50.0\% in Rwanda [16], 48.7\% in Tanzania [17] and 84.7\% in Burkina Faso [18]. High prevalence of intestinal parasitic infection in the region is associated with personal hygiene, socio economic status and educational level of the community.

The presence of intestinal parasitic infections may have multiple effects among children including physical and mental developments. The presence of chronic and heavy intestinal parasitic infection cause intestinal bleeding, malabsorption of nutrients, nutritional deficiency, destruction of cells and tissues and other associated effects. The overall effect of these results in growth retardation, reduced mental development, school absenteeism, low academic performance, susceptible to malnutrition and infection [19].

Several studies indicate the problem and severity of intestinal parasitic infection in Ethiopia. In line with this, continuous monitoring of intestinal parasitic infection and their associated risk factors are essential among school children in the country. There is no recent information about intestinal parasitic infection and associated risk factors in the study area. Therefore, the present study was aim to determine the prevalence of intestinal parasitic infection and associated risk factors among school children at Dona Berber primary school, Bahir Dar, Ethiopia.

\section{Methods \\ Study design and study area}

A school based cross-sectional study was conducted from October 2015 to June 2016 among students at Dona Berber primary school, Bahir Dar, Ethiopia. The school was located at the southern part of Bahir Dar city. Bahir Dar is located at $11^{\circ} 6^{\prime} \mathrm{N}, 37^{\circ} 38^{\prime} \mathrm{E}$ and about $578 \mathrm{~km}$ far from the capital city of the country, Addis Ababa. Bahir Dar is one of the fast growing cities in the country and serves as capital city of Amhara regional state. According to 2007 national population census, the city serves as home for about 180,094 people, of which majority of them are children [20].

\section{Study population and sample size determination}

The population of the study was students attending at Dona Berber primary school from grade 1 to grade 4 . The total numbers of students from grade 1 to grade 4 were 1274 in the study period. A total of 19 classes in the school and each class contain an average of 67 students. The target students were selected by stratified sampling based on their educational level (from grade 1 to grade 4) and quota was allocated to each grade based on the total number of students. The actual numbers of students participated in the study from each class were selected by systematic random sampling using class roster as reference.

The sample size was determined by statistical formula $\mathrm{n}=\mathrm{Z}^{2} \mathrm{xP}(1-\mathrm{P}) / \mathrm{d}^{2}$ where $\mathrm{P}$ (prevalence of intestinal parasite in the area), d (at 5\% marginal error) and standard score $(Z)$ at $95 \%$ confidence interval. The prevalence of intestinal parasitic infection in Bahir Dar was reported as $41 \%$ [21]. The sample size determined for the study was 372 . In order to minimize errors caused by dropout, the sample size were increased by $5 \%$. The final sample size used in the study was 390 .

\section{Sample collection and processing}

Structured questionnaire were prepared to gather relevant information from each student. Selected students for the study were interviewed to obtain information about age, grade, sex, religion, water sources, toilet availability, family education, family income, shoe wearing and hand washing habit. As the same time, the finger nail cleanness of each student was checked by data collectors. After collecting the information, all students were asked to bring fecal specimens using properly labeled stool cap with an applicator stick. About $2 \mathrm{~g}$ of stool specimens were collected from each student and mixed with $10 \%$ formalin for preservation.

The preserved fecal specimens were transported to the laboratory of Biology Department, Bahir Dar University. All specimens were processed using formal-ether fecal concentration techniques as indicated in WHO guidelines 
[22] by trained laboratory technologist. All developmental stages of parasite (cyst, egg, larvae, adult worm and worm segment) were recorded.

\section{Quality control}

Among the total positive samples, $10 \%$ were selected randomly for re-examination. The selected samples were processed and examined by experienced laboratory technologist who did not have information about the previous result. The results of the new laboratory examination were used as a quality control.

\section{Data analysis}

Statistical package for social science (SPSS) version 20.0 were used to analyze the collected data. The associations of potential risk factors and presence of intestinal parasitic infection were performed by binary logistic regression analysis model. The results of the association were considered as significant when the $p$ value was below 0.05 .

\section{Results}

Socio-demographic characteristic of study participants

A total of 390 students were selected for this study. Among them, 31 (7.9\%) students were excluded from the analysis due to either incomplete information or insufficient fecal specimen production. As a result, 359 primary school children were involved in the study. Among these students, 182 (50.7\%) were female and the remaining 177 $(49.3 \%)$ male. The students participated in the study were age ranges from 7 to 14 years and from grade 1 to grade 4 (Table 1). The average age of the students involved in the study was $10.1(\mathrm{SD} \pm 2.2)$ years.

Prevalence of intestinal parasites among study participants Among the 359 students participated in the study, 235 (65.5\%) were infected by one or more parasitic organism (Table 2). The prevalence of intestinal parasitic infection was $32 \%$ and $33.5 \%$ among female and male students, respectively. The rate of single, double and triple parasitic infections were $174(48.5 \%), 58(16.2 \%)$ and $3(0.8 \%)$, respectively (Table 2). Nine intestinal parasitic organisms were recorded from the study participants. Among these intestinal parasites, $E$. histolytica/dispar was the most prevalent 88 (24.5\%) followed by hookworm 82 (22\%), A. lumbricoides 49 (13.6\%) and G. lamblia 41(11.4\%) (Table 2).

\section{Potential risk factors associated with intestinal parasites infection}

Univariate logistic regression analyses model showed that family size, drinking water sources, shoe wearing habit and fingernail cleanness were major risk factors for intestinal parasitic infection. Multivariate logistic regression analysis showed that student do not always wash their hand before meal $(\mathrm{AOR}=2.33$; 95\% CI, 1.29-4.19), drinking of well
Table 1 Sociodemographic characteristic of school children and their family at Dona Berber first cycle primary school, Bahir Dar, Ethiopia, 2015/2016

\begin{tabular}{|c|c|c|c|}
\hline Variables & Categories & Frequency & Percentage \\
\hline \multirow[t]{2}{*}{ Sex student } & Female & 182 & 50.7 \\
\hline & Male & 177 & 49.3 \\
\hline \multirow[t]{4}{*}{ Age of students } & $7-8$ & 102 & 28.4 \\
\hline & $9-10$ & 113 & 31.5 \\
\hline & $11-12$ & 87 & 24.2 \\
\hline & $13-14$ & 57 & 15.9 \\
\hline \multirow[t]{4}{*}{ Grade students } & 1 & 102 & 28.4 \\
\hline & 2 & 93 & 25.9 \\
\hline & 3 & 85 & 23.7 \\
\hline & 4 & 79 & 22 \\
\hline \multirow[t]{4}{*}{ Family size } & $>6$ & 97 & 27 \\
\hline & 6 & 123 & 34.3 \\
\hline & 5 & 96 & 26.7 \\
\hline & $<5$ & 43 & 12 \\
\hline \multirow{3}{*}{$\begin{array}{l}\text { Family monthly } \\
\text { income }\left(E^{a} B^{a}\right)\end{array}$} & $<500$ & 123 & 34.3 \\
\hline & $500-2000$ & 215 & 59.9 \\
\hline & $>2000$ & 21 & 5.8 \\
\hline \multirow[t]{4}{*}{ Father education } & Illiterate & 97 & 27 \\
\hline & Primary school & 169 & 47.1 \\
\hline & Secondary school & 43 & 12 \\
\hline & Diploma and above & 50 & 13.9 \\
\hline \multirow[t]{4}{*}{ Mother education } & Illiterate & 177 & 49.3 \\
\hline & Primary school & 138 & 38.4 \\
\hline & Secondary school & 25 & 7 \\
\hline & Diploma and above & 19 & 5.3 \\
\hline \multirow[t]{3}{*}{ Water source } & Well water & 63 & 17.5 \\
\hline & River & 25 & 7 \\
\hline & Pipe water & 271 & 75.5 \\
\hline \multirow[t]{2}{*}{ Hand washing habit } & Sometimes & 146 & 40.7 \\
\hline & Always & 213 & 59.3 \\
\hline \multirow[t]{3}{*}{ Shoe wearing habit } & Not at all & 20 & 5.6 \\
\hline & Sometimes & 134 & 37.3 \\
\hline & Always & 205 & 57.1 \\
\hline \multirow[t]{3}{*}{ Religion } & Muslim & 9 & 2.5 \\
\hline & Orthodox & 337 & 93.9 \\
\hline & Protestant & 13 & 3.6 \\
\hline \multirow[t]{2}{*}{ Finger cleanness } & Not clean & 125 & 34.8 \\
\hline & Clean & 234 & 65.2 \\
\hline \multirow[t]{2}{*}{ Toilet availability } & Not available & 67 & 18.7 \\
\hline & Available & 292 & 81.3 \\
\hline
\end{tabular}

${ }^{\mathrm{a}}$ Ethiopian birr 
Table 2 Prevalence of parasitic infection among children by sex at Dona Berber first cycle primary school in Bahir Dar, Ethiopia, 2015/2016

\begin{tabular}{|c|c|c|c|c|c|}
\hline \multicolumn{2}{|c|}{ Parasite species } & \multicolumn{3}{|c|}{ Parasite infected students by sex } & \multirow[b]{2}{*}{$\begin{array}{l}\text { Chi-Square } \\
P \text {-value }\end{array}$} \\
\hline & & Female No. (\%) & Male No. (\%) & Total No. (\%) & \\
\hline \multirow[t]{4}{*}{ Protozoa } & E. histolytica & $48(13.4)$ & $40(11.1)$ & $88(24.5)$ & 0.41 \\
\hline & G. lamblia & $18(5)$ & $23(6.4)$ & $41(11.4)$ & 0.36 \\
\hline & E. vermicularis & $0(0)$ & $1(0.3)$ & $1(0.3)$ & 0.31 \\
\hline & T. hominins & $3(0.8)$ & $2(0.6)$ & $5(1.4)$ & 0.68 \\
\hline \multirow[t]{5}{*}{ Helminths } & Hookworm & $39(10.9)$ & $43(12)$ & $82(22.8)$ & 0.52 \\
\hline & A. lumbricoides & $21(5.8)$ & $28(7.8)$ & 49 (13.6) & 0.24 \\
\hline & H. nana & $9(2.5)$ & $8(2.2)$ & $17(4.7)$ & 0.85 \\
\hline & S. stericoralis & $6(1.7)$ & $10(2.8)$ & $16(4.5)$ & 0.28 \\
\hline & T. trichiura & $5(1.4)$ & $5(1.4)$ & $10(2.8)$ & 0.96 \\
\hline \multicolumn{2}{|c|}{ Single infection } & $84(23.4)$ & $90(25.1)$ & $174(48.5)$ & 0.37 \\
\hline \multicolumn{2}{|c|}{ Double infection } & $29(8.1)$ & $29(8.1)$ & $58(16.2)$ & 0.91 \\
\hline \multicolumn{2}{|c|}{ Triple infection } & $2(0.6)$ & $1(0.3)$ & $3(0.8)$ & 0.58 \\
\hline \multicolumn{2}{|c|}{ Over all infection } & $115(32)$ & $120(33.4)$ & $235(65.5)$ & 0.34 \\
\hline
\end{tabular}

water $(\mathrm{AOR}=2.84 ; 95 \% \mathrm{CI}, 1.09-7.45)$, unclean finger nail $(\mathrm{AOR}=3.68 ; 95 \% \mathrm{CI}, 1.87-7.26)$ and irregular shoe wearing habits $(\mathrm{AOR}=2.85$; 95\% CI, 1.53-5.32) were independently predict intestinal parasitic infections (Table 3). Likewise, student belonging larger family size were at higher risk of infection by parasitic organism as compared with students with small family size (Table 3 ). The odd of being infected by parasitic infection were increased by 5 fold among students belonging to a family size of 6 as compared with small family size. The present study showed that there were no statistical significant association of intestinal parasitic infection with sex, grade, religion and age of students involved in the study $(p>0.05)$.

\section{Risk factors associated with E. histolytica/dispar and hookworm infection}

Entamoeba histolytica/dispar and hookworm were the most frequent intestinal parasites detected from the study participants (Table 2). Univariate logistic regression analysis showed that hand washing habit before meal, finger nail cleanness, and drinking water source were risk factors for $E$. histolytica/dispar infection. Drinking of well water $(\mathrm{AOR}=2.51 ; 95 \% \mathrm{CI}, 2.30-4.86)$, unclean finger nail $(\mathrm{AOR}=4.42 ; 95 \% \mathrm{CI}, 2.55-7.65)$ and irregular hand washing habit before meal $(\mathrm{AOR}=2.32$; 95\% CI, 1.56-3.97) were predict infections of E. histolytica/dispar (Table 4). Multivariate logistic regression analysis indicated that shoe wearing habit was the independent risk factor for hookworm infection. Absence of shoe (AOR = 10.92; 95\% CI, 3.72-32.06) and irregularly use of protective shoe $(\mathrm{AOR}=14.13 ; 95 \% \mathrm{CI}, 7.06-28.29)$ were independently predict hookworm infection (Table 4).

\section{Discussion}

Epidemiological studies on the prevalence of intestinal parasitic infection and predisposing risk factors in school children are essential to design appropriate intervention strategies. The present study was therefore aim to assess the prevalence of intestinal parasitic infection and associated risk factors in school children. The overall prevalence of intestinal parasitic infection in the present study was $65.5 \%$, which is comparable with $65 \%-71 \%$ reported from different parts of Ethiopia [23, 24] and Morocco [25]. The present finding was a bit higher in comparison with $26.2 \%$ $-54.5 \%$ reported in different parts of Ethiopia [8, 26, 27] and those of 50\% [16], 48.7\% [17], 30\% [28] and 42.3\% [29] reported from Rwanda, Tanzania, Sudan and Iran, respectively. In contrast to our finding, high prevalence of intestinal parasitic infections were reported from Ethiopia (71.8\% - 95\%) [12-14, 30, 31], Central Sudan (90.4\%) [15], Burkina Faso (84.7\%) [18] and Yemen (90\%) [32]. These reported differences in prevalence of intestinal parasites among different studies might be associated with difference in parasitological methods used, level of environmental sanitation, drinking water source, family education and personal hygiene. High prevalence of intestinal parasitic infection is a direct manifestation of poor environmental sanitation and low level of awareness.

The most prevalent intestinal parasite in the present study was E. histolytica/dispar (24.5\%), which is in agreement with $21.6 \%$ - $27.3 \%$ reported from school children elsewhere $[13,14]$. The present finding revealed high prevalence of E. histolytica/dispar in comparison with $8.2 \%$ $-17.1 \%$ reported from different parts of Ethiopia [24, 30, 33], 15.5\% in Sudan [28] and 8.2\% in Saudi Arabia [34]. In contrast to our finding, high prevalence E. histolytica/dispar 
Table 3 Bivariate and multivariate logistic regression analysis of potential risk factors associated with parasitic infection among children at Dona Berber first cycle primary school in Bahir Dar, Ethiopia, 2015/2016

\begin{tabular}{|c|c|c|c|c|c|c|}
\hline \multirow[t]{2}{*}{ Risk factors } & \multirow[t]{2}{*}{ Categories } & \multicolumn{2}{|l|}{ Parasitic infection } & \multirow[b]{2}{*}{ Total No (\%) } & \multirow{2}{*}{$\begin{array}{l}\text { Crude OR } \\
\text { (Cl 95\%) }\end{array}$} & \multirow{2}{*}{$\begin{array}{l}\text { Adjusted OR } \\
(\mathrm{Cl} 95 \%)^{\#}\end{array}$} \\
\hline & & Positive No (\%) & Negative No (\%) & & & \\
\hline \multirow[t]{4}{*}{ Family size } & Above 6 & $77(79.4)$ & $20(20.6)$ & $97(27)$ & $5.89(2.69-12.9)^{* *}$ & $3.62(1.37-9.59)^{*}$ \\
\hline & 6 & $90(73.2)$ & $33(26.8)$ & $123(34.3)$ & $4.17(2.01-8.66)^{* *}$ & $4.90(2.03-11.83)^{* *}$ \\
\hline & 5 & $51(53.1)$ & $45(46.9)$ & $96(26.7)$ & $1.73(0.83-3.60)$ & $2.79(1.14-6.85)^{*}$ \\
\hline & Less than 5 & $17(39.5))$ & $26(60.5)$ & $43(12)$ & 1.00 & 1.0 \\
\hline \multirow{3}{*}{$\begin{array}{l}\text { Family monthly } \\
\text { income }\left(\mathrm{ETB}^{@}\right)\end{array}$} & $<500$ & $102(82.9)$ & $21(17.1)$ & $123(34.3)$ & $6.48(2.42-17.3)^{* *}$ & $1.94(0.59-6.34)$ \\
\hline & $500-2000$ & $124(57.7)$ & $91(42.3)$ & $215(59.9)$ & $1.82(0.74-4.49)$ & $1.70(0.59-4.93)$ \\
\hline & $>2000$ & $9(42.9)$ & $12(57.1)$ & $21(5.8)$ & 1.00 & 1.00 \\
\hline \multirow[t]{4}{*}{ Father education } & Illiterate & $81(83.5)$ & $16(16.5)$ & $97(27)$ & $9.00(4.09-19.79)^{* *}$ & $1.67(0.52-5.39)$ \\
\hline & Primary school & $109(64.5)$ & $60(35.5)$ & $169(47.1)$ & $3.23(1.67-6.24)^{* *}$ & $1.68(0.66-4.25)$ \\
\hline & Secondary school & $27(62.8)$ & $16(37.2)$ & $43(12)$ & $3.00(1.29-6.99)^{*}$ & $1.23(0.41-3.69)$ \\
\hline & Diploma and above & $18(36)$ & $32(64)$ & $50(13.9)$ & 1.00 & 1.00 \\
\hline \multirow[t]{4}{*}{ Mother education } & Illiterate & $137(77.4)$ & $40(22.6)$ & $177(49.3)$ & $9.59(3.26-28.24)^{* *}$ & $1.88(0.45-7.84)$ \\
\hline & Primary school & $80(58)$ & $58(42)$ & $138(38.4)$ & $3.86(1.32-11.32)^{*}$ & $1.23(0.32-4.77)$ \\
\hline & Secondary school & $13(52)$ & $12(48)$ & $25(7)$ & $3.03(0.84-10.99)$ & $1.46(0.33-6.50)$ \\
\hline & Diploma and above & $5(26.3)$ & $14(73.7)$ & $19(5.3)$ & 1.00 & 1.00 \\
\hline \multirow[t]{3}{*}{ Drinking water source } & Well water & $56(88.9)$ & $7(11.1)$ & $63(17.6)$ & $5.64(2.48-12.82)^{* *}$ & $2.84(1.09-7.45)^{*}$ \\
\hline & River & $20(80)$ & $5(20)$ & $25(7)$ & $2.82(1.03-7.73)$ & $1.00(0.30-3.36)$ \\
\hline & Tape water & $159(58.7)$ & $112(41.3)$ & $271(75.5)$ & 1.00 & 1.00 \\
\hline \multirow[t]{2}{*}{ Hand washing habit } & Sometimes & $118(80.8)$ & $28(19.2)$ & $146(40.7)$ & $3.46(2.11-5.66)^{* *}$ & $2.33(1.29-4.19)^{* *}$ \\
\hline & Always & $117(54.9)$ & $96(45.1)$ & $213(59.3)$ & 1.00 & 1.00 \\
\hline \multirow[t]{3}{*}{ Shoe wearing habit } & Not at all & $19(95)$ & $1(5)$ & $20(5.6)$ & $16.73(2.20-127.4)^{*}$ & $7.80(0.88-69.39)$ \\
\hline & Sometimes & 107 (79.9) & $27(20.1)$ & $134(37.3)$ & $3.49(2.11-5.77)^{* *}$ & $2.85(1.53-5.32)^{* *}$ \\
\hline & Always & $109(53.2)$ & 9646.8) & $205(57.1)$ & 1.00 & 1.00 \\
\hline \multirow[t]{2}{*}{ Fingernail cleanness } & Not clean & $108(86.4)$ & 17 (13.6) & $125(34.8)$ & $5.35(3.02-9.49)^{* *}$ & $3.68(1.87-7.26)^{* *}$ \\
\hline & Clean & $127(54.3)$ & $107(45.7)$ & $234(65.2)$ & 1.00 & 1.00 \\
\hline \multirow[t]{2}{*}{ Toilet availability } & Not available & $60(89.6)$ & $7(10.4)$ & $67(18.7)$ & $0.17(0.07-0.40)^{* *}$ & $0.74(0.27-2.04)$ \\
\hline & Available & $175(59.9)$ & $117(40.1$ & $292(81.3)$ & 1.00 & 1.00 \\
\hline \multirow[t]{2}{*}{ Sex of students } & Female & $115(63.2)$ & $67(36.8)$ & $182(50.7)$ & $0.82(0.53-1.26)$ & - \\
\hline & Male & $120(67.8)$ & $57(32.2)$ & $177(49.3)$ & 1.00 & \\
\hline \multirow[t]{4}{*}{ Age (years) } & $7-8$ & 70 (68.6) & $32(31.4)$ & $102(28.4)$ & $1.09(0.55-2.18)$ & - \\
\hline & $9-10$ & $74(65.5)$ & 39 (34.5) & $113(31.5)$ & $0.95(0.48-1.86)$ & - \\
\hline & $11-12$ & $53(60.9)$ & 34 (39.1) & $87(24.2)$ & $0.78(0.39-1.57)$ & - \\
\hline & $13-14$ & $38(66.7)$ & 19 (33.3) & $57(15.9)$ & 1.00 & \\
\hline \multirow[t]{4}{*}{ Grade } & 1 & 70 (68.6) & $32(31.4)$ & $102(28.4)$ & $1.49(0.81-2.75)$ & - \\
\hline & 2 & 61 (65.6) & $32(34.4)$ & $93(25.9)$ & $1.29(0.70-2.41)$ & - \\
\hline & 3 & $57(67.1)$ & $28(32.9)$ & 85 (23.7) & $1.39(0.73-2.62)$ & - \\
\hline & 4 & $47(59.5)$ & $32(40.5)$ & $79(22)$ & 1.00 & \\
\hline \multirow[t]{3}{*}{ Religion } & Muslim & $5(55.6)$ & $4(44.4)$ & $9(2.5)$ & $0.78(0.14-4.39)$ & - \\
\hline & Orthodox & $222(65.9)$ & $115(34.1)$ & 337 (93.9) & $1.21(0.39-3.77)$ & - \\
\hline & Protestant & $8(61.5)$ & $5(38.5)$ & $13(3.6)$ & 1.00 & \\
\hline
\end{tabular}


Table 4 Binary logistic regression analysis of potential risk factors associated with E. histolytica/dispar and hookworm infection among children at Dona Berber first cycle primary school in Bahir Dar, Ethiopia, 2015/2016

\begin{tabular}{|c|c|c|c|c|c|c|}
\hline \multirow{2}{*}{$\begin{array}{l}\text { Dependent } \\
\text { variables }\end{array}$} & \multirow[t]{2}{*}{ Categories } & \multicolumn{3}{|c|}{ E. histolytica/dispar } & \multirow{2}{*}{$\begin{array}{l}\text { Crude OR } \\
\text { (Cl 95\%) }\end{array}$} & \multirow{2}{*}{$\begin{array}{l}\text { Adjusted OR } \\
\text { (Cl 95\%) \# }\end{array}$} \\
\hline & & Positive No (\%) & Negative No (\%) & Total No (\%) & & \\
\hline \multirow[t]{3}{*}{ Water source } & Well water & $28(44.4)$ & $35(55.6)$ & $63(17.5)$ & $3.07(1.72-5.47)^{* *}$ & $2.51(2.30-4.86)^{* *}$ \\
\hline & River & $4(16)$ & $21(84)$ & $25(7)$ & $0.73(0.24-2.22)$ & $0.36(0.11-1.19)$ \\
\hline & Tape water & $56(20.7)$ & $215(79.3)$ & $271(75.5$ & 1.00 & 1.00 \\
\hline \multirow[t]{2}{*}{ Hand washing habit } & Sometimes & $53(36.3)$ & $93(63.7)$ & $146(40.7)$ & $2.99(1.77-4.76)^{* *}$ & $2.32(1.56-3.97)^{* *}$ \\
\hline & Always & $35(16.4)$ & $178(83.6)$ & $213(59.3)$ & 1.00 & 1.00 \\
\hline \multirow[t]{2}{*}{ Fingernail cleanness } & Not clean & $55(44)$ & $70(56)$ & $115(34.8)$ & $4.79(2.87-7.97)^{* *}$ & $4.42(2.55-7.65)^{* *}$ \\
\hline & Clean & $33(14.1)$ & $201(85.9)$ & $234(65.2)$ & 1.00 & 1.00 \\
\hline \multirow[t]{4}{*}{ Toilet availability } & Not available & $25(37.3)$ & $42(62.7)$ & $67(18.7)$ & $0.46(0.26-3.82)^{*}$ & $0.88(0.45-1.74)$ \\
\hline & Available & $63(21.6)$ & $229(78.4)$ & $292(81.3)$ & 1.00 & 1.00 \\
\hline & & & Hook worm & & & \\
\hline & & Positive No (\%) & Negative No (\%) & Total No (\%) & & \\
\hline \multirow[t]{3}{*}{ Shoe wearing habit } & Not at all & $8(40)$ & $12(60)$ & $20(5.6)$ & $10.72(3.7-31.2)^{* *}$ & $10.92(3.7-32.1)^{* *}$ \\
\hline & Sometimes & $62(46.3)$ & $72(53.7)$ & $134(37.3)$ & $13.85(7.1-27.2)^{* *}$ & $14.13(7.1-28.3)^{* *}$ \\
\hline & Always & $12(5.9)$ & $193(94.1)$ & $205(57.1)$ & 1.00 & 1.00 \\
\hline \multirow[t]{2}{*}{ Toilet availability } & Not available & $23(34.3)$ & $44(65.7)$ & $67(18.7)$ & $0.48(0.27-0.87)^{*}$ & $1.09(0.57-2.08)$ \\
\hline & Available & $59(20.2)$ & $233(79.8)$ & $292(81.3)$ & 1.00 & 1.00 \\
\hline
\end{tabular}

Not: ${ }^{*}=p<0.05,{ }^{* *}=p<0.01, \#=$ adjusted (multivariate regression model) for drinking water source, finger nail cleanness, hand washing habit before meal and toilet availability for E. histolytic/dispar and shoe wearing habit and toilet availability for hookworm infection

were reported from Rwanda (54.5\%) [16], Burkina Faso (66.5\%) [18] and Yemen (64\%) [32]. The difference in prevalence of $E$. histolytica/dispar among different studies might be explained by difference in level of contamination of drinking water source, consumption of raw vegetables and hand washing habits of the study participants. Hand washing habit among study participants, consumption of raw vegetables and level of environmental contamination are varied from locality to locality that results in difference in prevalence of amoebic infection among studies.

Hookworm was the second most prevalence parasitic infection among students in the study, which is in agreement with $19 \%-22.8 \%$ reported elsewhere [13, 31, 35]. However, the prevalence of hookworm infection in the present study was lower than other studies reported from Ethiopia [24, 33] and Western Cote D'Ivoire [36]. These variations in prevalence of hookworm infection among studies could be attributed to difference in environmental sanitation, shoe wearing habit of the students and differ in parasitological methods used during the study. High prevalence of hookworm infections among children was generally reported from rural areas with absence of protective shoe.

The present finding showed that E. histolytica/dispar infection was strongly associated with drinking water source, hand washing habit and unclean finger nail. In line with the present finding, the association of E. histolytica/dispar with drinking water source and hand washing habit before meal was reported elsewhere [37, 38]. Contamination of drinking water source, poor personal hygiene and lack of regular hand washing habits are major contributing factors for high E. histolytica/dispar infection.

The most important determinant of hookworm infection in the present study was shoe wearing habit of the study participants. The likely hood of being infected by hookworm was increased more than 10 folds among students who did not use protective shoe as compared with students regularly use protective shoe. The association of hookworm infection and shoe wearing habit is supported by several studies reported elsewhere [7, 9, 31, 39]. Lack of regular shoe wearing habit is known to be the major contributing factor that leads to high hookworm infection. This finding indirectly indicates the contamination of locality and playground of students with human fecal matters.

Polyparasitism is one of the common problems in developing countries. The prevalence of multiple parasitic infections in the present study was about $17 \%$, which is in agreement with $18.5 \%$ [40] and 18.4\% [24] reported from Central Sudan and Motta Town, respectively. However, our finding is lower than other reports from Ethiopia (28.5\%) [13] and Burkina Faso (53.5\%) [18]. The difference in prevalence of multiple parasitic infections at a time might be varied in relation to level of environmental contamination, level of awareness about parasitic infection and socioeconomic factors. This finding suggests that there might be low level of knowledge, attitude and practice towards intestinal parasitic infection in the study area. 
The present study showed that family size, drinking water source, hand washing habit of before meal, shoe wearing habit and finger nail cleanness were strongly associated with the presence of intestinal parasitic infection. Similar association of intestinal parasitic infection with the aforementioned variables was reported from Ethiopia [24] and Saudi Arabia [41]. Hands and fingers of students might be easily contaminated with soil that contains cyst and eggs of parasitic organism that leads to intestinal infection.

The present study showed that family size was strongly associated with intestinal parasitic infection. The likely hood of being infected by intestinal parasites was increased by about 5 folds among students belonging in a family size of above 5 as compared with students belonging in a small family size. The present finding is in agreement with other studies conducted in Ethiopia [8, 27, 42], Iran [43] and Saudi Arabia [41]. The possible explanation of this association might be related to personal hygiene, environmental sanitation and other nutritional related problems. As a family size increase, there might be a problem of overcrowding, undernutrition, poor sanitation and personal hygiene within the family that create ideal condition for parasitic transmission as well as increase susceptibility of family members to parasitic infections.

The risk of being infected by intestinal parasitic infection were increased by 2 folds among students who do not frequently wash their hand before meal as compared with students regularly washed their hand before meal. Similar association of intestinal parasites and hand washing habit of students were reported from Ethiopia [13, 24, 31, 44] and Saudi Arabia [41]. Likewise, the likely hood of being infected by intestinal parasites were increased by nearly 3 folds among students do not frequently used protective shoe as compared with student regularly used protective shoe. Similar findings of association between intestinal parasitic infection and shoe wearing habit of students were reported from elsewhere [13, $24,26,42]$. The possible explanations of association of shoe wearing habit and increase parasitic infection might be due to increase chance of hookworm and S. stercoralis infection. Lack of protective shoe is known risk factors to increase the chance of hookworm and S. stercoralis infection.

Finger cleanness and source of drinking water were strongly associated with presence of intestinal parasites. The risks of being infected by intestinal parasites were increased by 3.68 folds among students with unclean finger nail as compared with students who have clean finger nail. Similar association of intestinal parasitic infection with unclean finger nail were reported in different parts of Ethiopia [13, 27, 42, 44] and Saudi Arabia [41]. Similarly, the likely hood of being infected by intestinal parasites was increased by nearly 3 folds among students who drink well water as compared with students who drink tape water. The present finding of association of intestinal parasite with drinking water is supported by other results reported elsewhere [14, 24, 31].

\section{Conclusions}

The present study revealed that there is high prevalence of intestinal parasitic infection among student in the target primary school. Among the different potential risk factors assessed in the study larger family size, poor hand washing habit, unclean finger nail, drinking water source and absence of protective shoe were strongly associated with intestinal parasitic infection. Therefore, all stakeholders should give attention to raise awareness about control of intestinal parasitic infection, personal and environmental hygiene, and improving the quality of drinking water source.

\section{Abbreviations}

AOR: Adjusted odd ratio; Cl: Confidence interval; COR: Crude odd ratio; SPSS: Statistical package for social science; WHO: World health organization

\section{Acknowledgment}

The author forward special thanks to Bahir Dar University for financial support of the study. In addition, I would like to thanks for students, teachers and school community of Dona Berber primary school.

\section{Funding}

Not applicable.

\section{Availability of data and materials}

The datasets used and/or analyzed during the current study are available from the corresponding author on reasonable request.

Author's contribution

$\mathrm{TH}$ involved in design and conducts of the study, data analysis, interpret the findings and draft the manuscript.

Author information

Tamirat Hailegebriel (MSc) working as lecturer position in the department of Biology, Bahir Dar University, P.O. Box 79, Bahir Dar, Ethiopia.

Competing interests

The author declares that he/she has no competing interests.

Consent for publication

Not applicable.

Ethical approval and consent to participate

The study was conducted after approval of the project by ethical review committee of science college, Bahir Dar University. Students were involved in the study after receiving verbal consent from their family/guardians. All the laboratory results were communicated to the family/guardians of each student and students positive for intestinal parasitic infection were treated free of charge.

\section{Declarations}

I declared that this research article is my original work and all concerned bodies are well acknowledged. This manuscript is neither submitted to other journals for publication nor used for fulfillment of academic work.

\section{Publisher's Note}

Springer Nature remains neutral with regard to jurisdictional claims in published maps and institutional affiliations.

Received: 8 March 2017 Accepted: 15 May 2017

Published online: 23 May 2017

References

1. Okyay P, Ertug S, Gultekin B, Onen O, Beser E. Intestinal parasites prevalence and related factors in school children, a western city sample-Turkey. BMC Public Health. 2004:4(64). 
2. Mohammed K, Abdullah M, Omar J. Intestinal parasitic infection and assessment of risk factors in North-western. Nigeria: A Community Based Study IJPMBS. 2015;4(2):141-5.

3. Awasthi S, Bundy D, Savioli L. Helminthic infections. BMJ. 2003:323:431-3.

4. WHO: Soil-transmitted helminth infections. Geneva: WHO; 2016.

5. Harhay M, Horton J, Olliro P. Epidemiology and control of human gastrointestinal parasites in children. Expert Rev Anti-Infect Ther. 2010;8(2):219-34.

6. Alum A, Rubino J, Ljaz M. The global war against intestinal parasites should we use a holistic approach? IJID. 2010;14:e732-8.

7. Endris M, Lemma W, Belyhun Y, Moges B, Gelaw A, Anagaw B, et al. Prevalence of intestinal parasites and associated risk factors among students of Atse fasil general elementary school Azezo, northwest. Ethiopia Ethiop J Health Biomed Sci. 2010;3(1):25-33.

8. Abera A, Nibret E. Prevalence of gastrointestinal helminthic infections and associated risk factors among schoolchildren in Tilili town, northwest Ethiopia. Asian Pac J Trop Med. 2014:525-30.

9. Tadesse $\mathrm{G}$. The prevalence of intestinal helminthic infections and associated risk factors among school children in Babile town, eastern Ethiopia. Ethiop J Health Dev. 2005;19(2):140-7.

10. Abossie A, Seid M. Assessment of the prevalence of intestinal parasitosis and associated risk factors among primary school children in Chencha town, Southern Ethiopia. BMC Public Health. 2014:14(166).

11. Gelaw A, Anagaw B, Nigussie B, Silesh B, Yirga A, Alem M, et al. Prevalence of intestinal parasitic infections and risk factors among schoolchildren at the University of Gondar Community School, Northwest Ethiopia: a crosssectional study. BMC Public Health. 2013:13(304).

12. Erko $B$, Medhin G. H B: intestinal parasitic infections in Bahir Dar and risk factors for transmission. Tropical Med. 1995;37(2):73-8.

13. Alamir M, Awoke W, Feleke A. Intestinal parasites infection and associated factors among school children in Dagi primary school, Amhara National Regional State. Ethiopia Health. 2013;5(10):1697-701.

14. Ayalew A, Debebe T, Worku A. Prevalence and risk factors of intestinal parasites among Delgi school children, North Gondar. Ethiopia J Parasitol Vector Biol. 2011;3(5):75-81.

15. Ahmed A, Afifi A, Malik E. I a: intestinal protozoa and intestinal helminthic infections among schoolchildren in Central Sudan. Asian Pac J Trop Med. 2010:92-293.

16. Emile N, Bosco N, Karine B. Prevalence of intestinal parasitic infections and associated risk factors among Kigali Institute of Education students in Kigali. Rwanda Tropical Biomed. 2013;30(4):718-26.

17. Speich B, Marti H, Ame S, Ali S, Bogoch I, Utzinger J, Albonico M, Keiser J: Prevalence of intestinal protozoa infection among school-aged children on Pemba Island, Tanzania, and effect of single-dose albendazole, nitazoxanide and albendazole-nitazoxanide. Parasit Vectors. 2013; 6(3).

18. Erismann S, Diagbouga S, Odermatt P, Knoblauch A, Gerold J, Shrestha A, Grissoum T, Kaboré A, Schindler C, Utzinger J et al: Prevalence of intestinal parasitic infections and associated risk factors among schoolchildren in the plateau Central and Centre-Ouest regions of Burkina Faso. Parasit Vectors .2016; 9:554.

19. Brooker S. Estimating the global distribution and disease burden of intestinal nematode infections: adding up the numbers - a review. Int J Parasito. 2010;40(10):1137-44.

20. Agency CS. Summary and statistical report of the 2007 population and housing Sensus: in. Federal Democratic Ethiopia Population Sensus commession, Addis Ababa, Ethiopia. 2008;113

21. Abera B, Biadegelgen F, Bezabih B. Prevalence of salmonella typhi and intestinal parasites among food handlers in Bahir Dar town. Northwest Ethiopia Ethiop J Health Deve. 2009;24(1):46-50.

22. WHO: Basic laboratory methods in medical parasitology. Geneva; WHO; 1991.

23. Mathewos B, Alemu A, Woldeyohannes D, Alemu A, Addis Z, Tiruneh M, Aimero M, Kassu A: Current status of soil transmitted helminths and Schistosoma manson infection among children in two primary schools in North Gondar, Northwest Ethiopia: a cross sectional study. BMC Research Notes. 2014; 7(88).

24. Andualem M. Parasitic infection and associated factors among the primary school children in Motta town, western Amhara. Ethiopia Am J Public Health Res. 2014;2(6):248-54.

25. Fatni C, Fatni H, Romero D, Olmo F, Rosales M. Intestinal parasitism in Moroccan children: comparative quantitative study of the Faust's and Ritchie's coprologic methods. IJISR. 2014;11(1):53-64.

26. Tulu B, Taye S, Amsalu E. Prevalence and its associated risk factors of intestinal parasitic infections among Yadot primary school children of south eastern Ethiopia: a cross-sectional study. BMC Research Notes. 2014;7(1):848.
27. Wale M, Wale M. T F: the prevalence of intestinal helminthic infections and associated risk factors among school children in Lumame town, northwest. Ethiopia. J Parasitol Vector Biol. 2014;6(10):156-65.

28. Muhajir A, Hajissa K, Mohamed Z, Abdel-Aal A. Prevalence of intestinal parasitic infection among children in al-kalakla, Khartoum. Sudan World Appl Sci J. 2017:35(2):219-22.

29. Bahmani P, Mleki A, Sadeghi S, Shamoradi B. E G: prevalence of intestinal protozoa infections and associated risk factors among schoolchildren in Sanandaj City. Iran Iran J Parasitol. 2017;12(1):108-16.

30. Mekonnen B, Erko B, Legesse M. Prevalence of intestinal parasitic infections and related risk factors among street dwellers in Addis Ababa. Ethiopia J Trop Dise. 2014;2:132.

31. Alemu A, Atnafu A, Addis Z, Shiferaw Y, Teklu T, Mathewos B, Birhan W, Gebretsadik S, Gelaw B: Soil transmitted helminths and Schistosoma mansoni infections among school children in zarima town, northwest Ethiopia. BMC Infectious Disease. 2011; 11(189).

32. Alwabr G, Al-Moayed E. Prevalence of intestinal parasitic infections among school children of al-Mahweet governorate. Yemen Eur J Biol Res. 2016;6(2):64-73.

33. Legesse M. B: E: prevalence of intestinal parasites among school children in rural area close to the south east of lake Langano. Ethiopia Ethiop J Health Deve. 2004;18(2):116-20.

34. UNHCR. Factsheet - ETHIOPIA. In: UNHCR. 2016:1-4.

35. Hailu T. Current prevalence of intestinal parasites emphasis on hookworm and Schistosoma mansoni infections among patients at Workemeda health center. Northwest Ethiopia Clin Microbiol. 2014;3(4):155.

36. Rasoa G, Vounatsoua P, Gosoniua L, Tannera M, N'Goranb E, Utzingera J. Risk factors and spatial patterns of hookworm infection amongschoolchildren in a rural area of western Côte d'Ivoire. Int J Parasitol. 2006;36(2):201-10

37. Benettona M, Gonçalvesb A, Meneghinic M, Silvab E, Carneirob M. Risk factors for infection by the Entamoeba Histolytica/E. dispar Complex: an epidemiological study conducted in outpatient clinics in the city of Manaus, Amazon region, Brazil. Trans R S Trop Med Hyg. 2004;99(7):532-40.

38. Shahrul Anuar S, Al-Mekhlafi H, Abdul-Ghani M, Osman E, Mohd Yasin A, Nordin A, et al. Prevalence and risk factors associated with Entamoeba istolytica/dispar/moshkovskii infection among three orang Asli ethnic groups in Malaysia. PLoS One. 2012;7(10):e48165.

39. Strunz E, Addiss D, ME S, Ogden S, Utzinger J, Freeman M: Water, sanitation, hygiene, and soil-transmitted helminth infection: a systematic review and meta-analysis. PLoS Med 2014; 11(3):e1001620.

40. Ahmed A, Afifi A, Malik E, Adam I. Intestinal protozoa and intestinal helminthic infections among schoolchildren in Central Sudan. Asian Pac J Trop Med. 2010:292-3.

41. Al-Mohammed H, Amin T, Aboulmagd E, Hablus H, Zaza B. Prevalence of intestinal parasitic infections and its relationship with socio-demographics and hygienic habits among male primary schoolchildren in Al-Ahsa, Saudi Arabia. Asian Pac J Trop Med. 2010:906-12.

42. Elfu B: Nutritional Status and Intestinal Parasite in School Age Children: A Comparative Cross-Sectional Study. Int J Pediatr. 2016; Article ID 1962128:8.

43. Masoumeh $R$, Farideh $T$, Mitra $S$, Heshmatollah T. Intestinal parasitic infection among school children in Golestan Province. Iran Pak J Biol Sci. 2012;15:1119-25.

44. Haftu D, Deyessa N, Agedew E. Prevalence and determinant factors of intestinal parasites among school children in Arba Minch town, southern Ethiopia. Am J Public Health Res. 2014:2(5):247-54.

\section{Submit your next manuscript to BioMed Central and we will help you at every step:}

- We accept pre-submission inquiries

- Our selector tool helps you to find the most relevant journal

- We provide round the clock customer support

- Convenient online submission

- Thorough peer review

- Inclusion in PubMed and all major indexing services

- Maximum visibility for your research

Submit your manuscript at www.biomedcentral.com/submit 